\title{
The Glotopolitical Perspective and the Linguistic Standardization: Perspectives About the Portuguese Language
}

\author{
Sweder Souza \\ Post-Graduate Program of Letters, Federal University of Paraná \\ Rua General Carneiro, 460, $10^{\circ}$ andar - sala 1018/1019, Curitiba, Paraná, PR, Brazil \\ Tel: 55-41-99765-6322_E-mail: swedersouza@gmail.com
}

Received: December 1, 2020

Accepted: January 8, 2021 Published: January 12, 2021

doi:10.5296/elr.v7i1.18175

URL: https://doi.org/10.5296/elr.v7i1.18175

\begin{abstract}
This paper discusses the glotopolitical perspective, understood as any and all political and social action, conscious or not, about language (Guespin \& Marcellesi, 1986; Lagares, 2018) and some Portuguese Language nominations - language as Hypostasis (Bagno, 2011, 2019), Official State/National Language (Faraco, 2008, 2016) and Mother Tongue -, so that readers have a broad theoretical-methodological panel of research in the theoretical field of glotopolitics and linguistics, which here come into clashes, confluences and displacements.
\end{abstract}

Keywords: Glotopolitics, Portuguese Language Nominations, Linguistic Standardization.

\section{Introduction: The Glotopolitical Perspective}

Among the various understandings of the term Language Policy (LP), one of them is specifically related to planning, that is, with the explicit adoption of political decisions about languages that are then implemented with the help of technical specialists in language and/or education.

Thus, a broader notion considers that any political action that has an impact on social relations also has a glotopolitical reading, since any social change implies some kind of change in linguistic relations.

In the midst of the LP discussions and in their relationship with the planning and standardization of the language, it is interesting to look closely at the recent questions reviewed by Lagares (2018), on the glotopolitical perspective, since it is necessary to include all the facts of the language where society's action ultimately takes the form of politics. In 
other words, glotopolitics here is situated as a perspective, a way of looking at certain facts. Thus, the term Linguistic Policy can have several meanings, as will be seen later. In his theoretical support, Lagares (2018) mentions the text: Pour la Glotopolitique, by Guespin and Marcellesi (1986), as one of the foundational texts of glotopolitical issues, because for these authors, according to Lagares (2018),

(...) a democratic language policy would require linguistic information in two directions. Language decision-makers should know that users need to participate in discussions and their own implementation, considering that language debates are part of confrontations in which issues concerning the relationship between social identities and language practices interact. Users should also have elements to develop their language representations (...) (Lagares, 2018: 33 , free translation).

In the words of Guespin and Marcellesi (1986), glotopolitics should be concerned "(...) to act not only on the status of languages, but also on language practices and on the relationships, in the social individual, between thought and language (...)", as Lagares (2018: 33) and as Guespin and Marcellesi (1986) say:

We are led successively to evoke the two aspects of the interaction between language and society, but we want to insist on the intertwining of the two phenomena: every human society is linguistic, and every practice of language is social. This has practical consequences: it is not enough that we give ourselves a single object (the maintenance or transformation of a society conceived as a value in itself, on which we act through language, or the survival of an overvalued language, on which acts under pressure on society). The principles are abstract and fixative in both cases. The profound justification of glotopoly is not the alignment of linguistic or social practices with an abstract ideal of language or society; it is the development of the social personality (Guespin \& Marcellesi, 1986: 9, free translation).

Glotopolitics, then, studies interventions in the language space, understood in a broad sense, as they can be planned, explicit, voluntary, generated by agents, collective or individual, but they can also be identified or produced "spontaneously", without clearly identifiable mediators.

These interventions are exercised both in languages, in their varieties, in records, in speeches, and in the various articulations of the verbal apparatus with other semiotic systems. Thus, any social and political change can be analyzed through its glotopolitical effects, by the way that linguistic relations, from the point of view of the language system or concrete enunciative practices take place and act in society (Lagares, 2018).

In this sense, the term, or rather, the glotopolitical perspective, offers a "possibility to neutralize, without denying, the opposition between language and speech" (Guespin \& Marcellesi, 1986: 9). In other words, the glotopolitical perspective has to do with the different approaches and actions that a society exercises on Language. On the other hand, glotopolitics is always in action, aiming at linguistic practices that take place continuously, as it depends on verbal intentions. As Guespin and Marcellesi point out: 
Acts generally considered trivial, hardly worthy of observation (for example, the resumption of a "failure" by reference to a standard) are obviously not attributed to a language policy, or, more precisely, to research on the subject. The politics of language is hampered by the facts of this order: if the place of speech is official, if the resumption is the act of a master, if the lack involves a sanction, the descriptor will conclude the political fact; but if the situation is informal, if the executive is family, if recovery is the order of the board, he will have nothing to record. But recovery according to a pattern is identical in both cases; J. P. Kaminker and D. Baggioni (1980) emphasize the principle of normative correction, whether or not political and repressive intent. The concept of glotopolitics allows to take into account the identity between these two cases and their specificity; it includes concerted policies and the relays, conscious or unconscious, active or passive of these policies (Guespin \& Marcellesi, 1986, p. 15 , free translation).

Thus, glotopolitical issues range from small issues such as family environments to more important interventionist acts, that is, they are LPs that consist of discrete acts or not, in relation to decisions, recommendations, creation of instances etc., with a focus on action in one or more more language systems.

In this sense, glotopolitics

(...) it encompasses the politics of language: all cases of promotion, prohibition, equipment, changing the status of a language are eminently glotopolitical facts; the politics of language is, therefore, a special case of glotopoly, to be studied doubly, both in its relation of principle with other forms of glotopoly, and in its specificity as the only level that fascinates the masses, of a single domain where intervention politics is easily identifiable, and the relationship with ethnic identity is directly perceived, etc. (Guespin \& Marcellesi, 1986, p. 15, free translation).

This concept, then, can be reflected in two axes: the vertical, which links the normative issues of LPs and the horizontal, which encompasses social practices, contexts, etc. which, in turn, is larger than the vertical axis, which would be connected to the LPs. In this sense, "(...) any decision that changes social relations is, from the linguist's point of view, a glotopolitical decision" (Guespin \& Marcellesi, 1986: 15, free translation).

In this sense, the next step is to present the issues that directly involve the LPs, how they manifest themselves and influence the subjects, and also show how their planning occurs and how it reflects on the normative axis, in the face of the social practices' axis.

\section{Linguistic Standardization and Language Policy}

Decisions around Language Policy and Planning are made every day, both formally by governments, and informally, by academics and community leaders. These decisions influence the right to use and maintain the language, affect its status and determine policies. Language policies and planning decisions have a major impact on the vitality of language and, ultimately, on the rights of the individual and access to citizenship.

Decisions about language policies, requirements and practices have important consequences in 
all social contexts. For Cooper (1989), "language planning refers to deliberate efforts to influence the behavior of others in relation to the acquisition, structure or functional allocation of their language codes" (Cooper, 1989: 45).

It can be carried out with formal official government sanction or reflected in unofficial and informal practices. Language planning is often carried out with the express purpose of solving communication problems. However, poorly designed and ill-informed policies can result in negative impacts on the people affected by them. Traditionally, there are two dimensions of language planning, namely: corpus planning, which deals with the selection and codification of norms, as in grammar writing and standardization of spelling; status planning, which deals with the initial choice of language, including attitudes towards alternative languages and the political implications of various choices, according to Bright (1992).

A second type of important planning, particularly for education, is known as language acquisition planning (Cooper, 1989). The choice of which languages to use as a means of instruction is essential in planning the acquisition, as it is necessary not only to learn the language, but to use it to learn, as a means of instruction. The first concept listed here is that suggested by Kaplan and Baldauf (1997), under the argument that language is part of a broader linguistic planning process, that is,

(...) the exercise of language planning leads or is directed by the promulgation of a language policy by the government (or other authorized body or person). A language policy is a set of ideas, laws, regulations, rules and practices designed to achieve the planned language change in societies, groups or systems (Kaplan \& Baldauf, 1997: 11).

In this sense, the Language Policy (hereinafter LP or LPs, in the plural) is seen as a set of laws and regulations precisely approved by a competent body, that is, by a government, characterizing this approval as a language plan. The point is that Kaplan and Baldauf (1997) deal with the approval of these policies, which is not really necessary. LPs may emerge that do not require government approval, although not all formally proposed LPs are necessarily intentional or planned.

Schiffman (1996), on the other hand, bases LP issues on social constructions, thus,

(...) language policy is mainly a social construction. It may consist of several elements of an explicit nature - there may be legal, judicial, administrative, constitutional and/or legal jurisdictions in some jurisdictions, but whether or not a political entity has such an explicit text, politics as a cultural construction resides mainly in others conceptual elements - belief systems, attitudes, myths - the whole complex that we are referring to as linguistic culture, which is the sum total of ideas, values, beliefs, attitudes, prejudices, religious restrictions and all the cultural baggage 'that the speakers they bring to their relations with the language of their antecedents (Schiffman, 1996: 276).

In this definition are policies explicitly approved by a policy, but also politics as a cultural construct, which is based on the implicit beliefs, attitudes and ideologies of language within a speech community (Johnson 2013). In his book Language Policy, Spolsky (2004) distinguishes three aspects in LP of a speech community, which are: language practices - the 
usual pattern of selection among the varieties that make up his linguistic repertoire; language beliefs or ideologies - beliefs about the use of language and language; any specific efforts to modify or influence this practice by any type of intervention, planning or language management (Spolsky, 2004).

Spolsky (2004) defines such beliefs and ideologies as LPs. In addition, it includes language practices, which do not occur as a result or result from language policies, but as language policies in themselves. On the issues of Planning and Linguistic Management, Spolsky (2007) is attentive to the latter, as management deals with strategies, while planning deals with plans, approaching values and adaptable to different situations.

In short, the author proposes three independent but interrelated components, namely: the "real" language policy, related to the uses and variants that a subject makes and that marks a certain adequacy or alienation in relation to a given community; the second are the values attributed, by a given community, to the uses of variants and varieties, thus establishing values in relation to their importance; the third, management, which would be the efforts of subjects from certain communities, when they believe they have authority over others, to modify their linguistic practices, in order to change the use of different variants or varieties.

Spolsky (2007) still establishes the difference between the linguistic community, defined politically with the presence of several varieties; speech community, formed by smaller groups, such as family, a small town, where there is a network of linguistic interrelationships. Within these communities, the notion of scope of use, seen as a concrete space of interrelation, like a church, the workplace etc. According to these spheres, each has its own policy, which is influenced by external factors.

According Souza and Del Olmo (2019, p. 25),

(...) in a period characterized as "classic", which occurs between the years 1950 and 1960, Linguistic Planning is understood as: (...) a way to influence the future of languages, without intending, in any case, to fully predict them, according to a perfectly delimited project, as there is already a clear awareness that complex social dynamics can drive historical processes in different directions. The level of planning that is contemplated is that of the national State, at the service of "development" projects oriented, in theory, for the whole society, linking intervention on languages to the issue of social cohesion in the country (Lagares, 2018). About the reflections of this Planning, there is the "(...) idea that linguistic diversity is an obstacle to the modernization of society and to the economic development of countries" (Lagares, 2018: 21).

Here, issues of status come into play, as decisions are made about the hierarchy of languages and which ones will be officially recognized as national languages. Although nations have historically used LPs more frequently to promote an official language at the expense of others, today many countries are developing policies designed to protect and promote - to a greater and lesser extent - regional and ethnic languages whose viability is threatened. In this way, LP is seen as a set of laws, regulations or rules approved by an authoritarian body (such as a government) as part of a language plan (Kaplan \& Baudalfk 1997). 


\section{Glotopolitics and Some Language Concepts}

Based on a relevant political number, the National States recognized today by the United Nations (UN) total 193. While the approximate number of languages of humanity is 6,000 on the planet as a whole, according to Ethnologue. How do you accommodate 6,000 languages in 193 National States?

There are, then, problems of the most diverse orders, solutions of the most diverse orders and situations with no apparent solution. Therefore, the LP area is an infinite area, considering only this context, since the political problem is often not recognized, the linguistic issue is not recognized in the National States as a political problem, thus generating several conflicts.

Thus, the construction of a National State is a glotopolitical fact, since the Nations that are constituted, minimize internal differences, aiming to create an identity as uniform as possible.

In this sense, it is not necessary for LPs to be explicit for the event to exist. A National State does not need to declare a language official in the legal texts that constitute it so that, in fact, that language among all those spoken in its territory functions as such. However, National States are, in general, interventionist, and the vast majority assume a monolingual logic, since linguistic liberalism only exists as an ideology, made to justify the hegemony of one language over the others (Lagares, 2018).

Within these assumptions, and considering the scenario of Brazil, it is necessary to briefly characterize what the Language is called Hypostasis, National and Official Language and Mother and Portuguese Language.

\subsection{Language as Hypostasis}

Defining what a language is is always complicated. The language has many personalities, making it "practically impossible to separate what is properly linguistic, what belongs to the linguistic structure or system (if that exists), and what is cultural, social, political, ideological construct" (Bagno, 2019: 190, free translation).

As Bagno (2019) rightly points out, and according to the concept of language addressed in this work, as a resource, we know that there is no precise concept.

Paraphrasing what Bagno raises (2019), Saussure wrote that "the point of view creates the object" and, in this way, we bring it to the language, because whatever it is "does not allow itself to be fully grasped - it is necessary to choose one point from which we observe it to draw some conclusions, all of them always unstable, proteiform"(p. 191, free translation).

In this sense, in line with Bagno $(2011,2019)$, when a language goes through a process of standardization or standardization, it becomes a hypostasis. This process of hypostasis takes away from the language its "(...) private, intimate, community life and transforms it into an institution, a cultural monument, a vehicle for a national policy and which throughout history has become an imperial policy" (Bagno, 2011: 359, free translation). Thus, according to Bagno (2011) “(...) it is possible, in the general discourse about language, to speak of it as a subject, as if it were an entity endowed with will and power of action, for example, when it is 
said: "The Portuguese has more tenses than other Romance languages" (p. 357). In a philosophical sense, of origin, the constituted language, that is, the subject language, with wishes, decisions etc., would be

(...) what in philosophy is called hypostasis. The Greek word hypóstasis was translated into Latin by substantia. Christian theology used this term to define the dual nature of Christ, his double substance: human and divine at the same time. But in modern and contemporary philosophical reflection, according to the Houaiss dictionary, a hypostasis is a "cognitive mistake that is characterized by the attribution of concrete and objective existence (substantial existence) to a fictional reality, abstract or merely restricted to the incorporeal character of human thought" (Bagno, 2011: 358, free translation).

In this sense, the process of hypostasis occurs when the language begins to be embedded, mainly identified, in models of rules and norms, ceasing to be a sociocultural device, to become "the Language" (Bagno, 2019: 193), defined, imposed and institutionalized. Therefore, in this process of hypostasis, the language begins to be identified with this model, with this standard norm, as pointed out by Faraco (2008).

The case of the standard norm, not as a variety in which the speakers are not valued, but as a hypostasis, a social institution. Thus, the standardized language " $(. .$.$) is no longer a mother$ tongue and, supported by the law and serving as a code to write the law, becomes a paternal language, a linguistic pattern, the language of the country, the language of the boss (of the colonizer, for example)" (Bagno, 2011: 259).

With its limits well fixed and its essence transposed to grammars, dictionaries, style manuals and other normative elements, in an attempt to describe it to better prescribe it, this language of the motherland will have, at school, its main means of propagation, vehicle and transmission (Bagno, 2019).

Thus, we have difficulty in identifying language as something socio-cultural and political (...) which is the standard written standard of the national languages of the European powers. The process of transforming a language into a hypostasis always involves systematizing the written form of that language, creating an orthography.

The writing gives the "language", a mere abstraction, a concrete appearance, of a tangible, material thing, which can be touched, read, heard, drawn, erased, copied, embroidered, engraved in metal, sculpted in marble, etc. It is complete, completed, accomplished hypostasis. It is not surprising that for almost all people who live in graphocentric societies, language gets confused with writing, with the spelling of the language. And for that same reason, despite the efforts of contemporary linguists to prove that speech and writing have much more similarities than differences between them, writing (hypostasized in the literary writing of the great classics of the language) will always remain, in the imagination collective, in common sense, as something superior, more sublime and more worthy of veneration than speech (Bagno, 2019: 195, free translation).

Thus, this standardization, grammaticalization, spelling of the language causes a selection process and, consequently, an exclusion process. In this sense, It is evident that this 
political-ideological construct, this monumental hypostasis, has relations with the intimate life of human language, this powerful socio-cognitive faculty of interaction with the world and with other human beings. But this hypostasis is not "the language" in its entirety: it is only a small part, yes, but very important, from the historical and cultural point of view, of something so big and so complex that nobody knows how to define it to the satisfaction (Bagno, 2019: 217).

The language or "the variety chosen to be the official will be the object of a work of codification, of standardization" (Bagno 2019: 197), allowing it to be an instrument of high literature, science, religion and law. What we see in this process of hypostatization, then, will serve as a contribution to the understanding of what happens with LP in the document analyzed here.

\subsection{National Language and Official State Language}

According to the 13th article of the Federal Constitution "the Portuguese language is the official language of the Federative Republic of Brazil". In this case, when the expansion of Portuguese, the stories are full of anachronisms and triumphalisms (Faraco, 2016), as many historians claim that it was D. Dinis who transformed, in 1296, the "Portuguese" language into the "official" language of kingdom (Faraco, 2016: 23). But "what happened during the reign of D. Dinis was that the use of the vernacular Romanesque language in the documentation produced by the Royal Chancellery became systematic and supplanted the use of Latin" (p. 23).

The idea of making the language official, coming from D. Dinis, is mistaken, because one cannot confuse the making of Royal documents with the official language, since, in its modern sense, the official language means "language of mandatory use in all public instances "(p. 24).

At that time, teaching "continued to be done primarily in Latin until the 18th century" and doctors continued to prescribe in Latin until at least the 17th century (p. 24). In this period, it is also not possible to speak in the national language, since the process of national construction, in the modern sense, occurs from the 18th century onwards.

Returning to conceptual issues, the National Language and the Official Language can be understood as two concepts or categories with meanings that can coincide or can be intentionally separated. Some languages can be popularly recognized as National Languages, while others can enjoy a high degree of official recognition.

The National Language is always the language of the dominant social group, it is the product of the hegemony that it exercises throughout the State and, at the same time, it is a fundamental element for the maintenance of its social power. Thus, what defines the National Language is its hegemony, that is, when it becomes hegemonic in a given territory. Hegemonic means when it becomes natural, when its social presence expands other social functions of that language, it starts to include all social functions for the existence of the Nation. In this sense, the National Language starts to function as an Official Language of the State. 


\section{Macrothink}

Thus, the National Language is a language that undergoes interventions, it is a language in which one intervenes from the point of view of grammar. It is a grammaticalized language, to actually function as a Language of the Nation. Whereas the Official Language is that considered to be proper to a country, for example, the Portuguese Language is the Official Language of Brazil, just as Italian is the Official Language of Italy etc. All countries have their Official Language or their Official Languages, but always in a limited number. This Official Language governs Public Administration, Schools, Official Documents, etc.

The same is true of most native languages in the political-geographic space in which Lusophony has expanded - this term is used in Africa to refer to African languages that are not properly official, although some have the recognition of national languages, because the official language is the European language of colonization -, that is, the one that the country's citizens are able to use as a link between the peoples of different ethnicities.

As Lagares (2018) points out, “(...) the invention of a national language also means the invention of monolingualism” (p. 53). Thus, “(...) when the process of inventing the national language is successful, all linguistic realities that are not identified with it, as a side effect, are considered dialects (p. 57).

Likewise, according to Lagares (2018), the State acts in an interventionist manner, imposing this Official Language. Thus, the National Language is the language of the dominant social group, the product of a hegemony exercised throughout the State (Lagares, 2018).

\subsection{Mother Tongue and Portuguese Language}

The perspective of a mother tongue is the one we have as a first contact, the one spoken by our parents. This concept originates from an ideology that mothers were the only ones who educated their children in early childhood, making the mother's language the first to be assimilated by the child.

This basic definition of Mother Tongue (MT) has two factors: a certain juxtaposition with the concept of First Language (L1) and identity factors, since the subject, in some way, identifies with that MT.

Thus, the MT or L1, is the individual's first contact with his Linguistic Education, without a certain formal normativity - in reality, all linguistic relations are based on norms of use, that is, on normalization of practices -, because in this context he he is still testing his hypotheses about language, acquiring moral, personal values, etc., based on his environment.

In this sense, the child is in contact with other people, besides the mother, from the first moments of life: father, siblings, aunts, grandparents, cousins, from the community, in short, it is not linked only to the maternal figure, therefore, a child can acquire a language that is not spoken (or that is only spoken by some members of the family) at home and both are worth as $\mathrm{MT} / \mathrm{L} 1$.

According to an example already exposed by Souza and Del Olmo (2019): if a child is born in Brazil, his mother is French and his mother Spanish, if with each one she communicates in their respective languages and, in the school, in the neighborhood, with friends etc., 


\section{Macrothink

Portuguese is the daily language, this subject has three languages: French, Spanish and Portuguese (without meaning that the competence is equal in the three languages).

In teaching, above all, it is customary to speak of "mother tongue teaching", as if in fact what is taught in school was the subject's "home language", which, at times, may even seem like "teaching of a Foreign Language", as the official language of the school is Portuguese. Thus, the teaching of the mother tongue is often confused with the teaching of the Portuguese language, that is, of a National and Official State language and also as a hypostasis.

The subject entitled Portuguese, started late to be part of Brazilian education. Before the 19th century, what we had was the Portuguese Language (PL) for Literacy (Soares, 1996). Until the middle of the 18th century, when the Pombaline Reformation took place, Jesuits dominated Brazilian teaching with its pedagogical methodology, in which there was no room for the Portuguese language. From Literacy, he went directly to Latin, in a study program of the Society of Jesus used around the world, called Ratio Studiorum.

Published in 1599, this paradigm structured teaching into two cycles: the first, corresponding to the secondary, was divided into five classes, three of Grammar, one of Humanities and one of Rhetoric and lasted for six or seven years. The second, corresponding to higher education, comprised three years of Philosophy and four years of Theology (Malfacini, 2015: 46).

According to Malfacini (2015), three reasons can be deduced for PL not being part of the Curriculum until the first half of the 18th century. The first, who was educated, was part of classes that were privileged and, thus, followed the educational model of that time, with Latin as a status and classic learning. Like this,

(...) there was the assumption that the wealthiest social group, which would continue its studies, would be used to frequent reading and writing practices outside of school. For these students, coming from the dominant social class, the (re) knowledge of the prestige variety of the language would be nothing more than the school systematization of a language already spoken at home. Thus, the teaching of the Portuguese language was offered as a second language study, in continuity with a model already known for studying Latin grammar (Malfacini, 2015: 46-47, free translation).

The second reason would be the fact that PL is not yet part of social use, that is, it was not yet a National Language, but, rather, a General Language, permeated by others, such as indigenous languages. In fact, in the 18th century, Marques de Pombal, made the use of LP mandatory in Brazil, (...) justifying that it was the practice of a dominant nation to instill in the dominated people also the linguistic domain (Malfacini, 2015: 47).

On the other hand, the third reason, stems from the first two, since Portuguese had no basis to constitute itself as an area of knowledge that could be taken to school, as 
(...) it was the Pombaline Reform that changed this point of view, based on the proposal of Antônio Verney, author of The True Method of Studying, in 1746. In the treatise, the author proposes that, in addition to Literacy in Portuguese, the study of Portuguese grammar should precede the study / teaching of Latin grammar, which should be taught in comparison and contrast with the first. Only then did Portuguese become a curricular component, starting to be seen as instrumentalization for the teaching of Latin (Malfacini, 2015: 47, free translation).

Like this,

(...) the 50's (20th Century) brought an important contribution to the normative teaching of the language: the promulgation of Ordinance No. 36, of January 28, 1959, popularly known today as the Brazilian Grammatical Nomenclature (NGB). In order to simplify and unify the contents and the nomenclature studied in the country, the new NGB advised the vigor of its content as programmatic teaching and activities arising in schools throughout Brazil, starting in the academic year of 1959 (Malfacini, 2015: 48, free translation).

Still, according to Malfacini (2015: 48), until today we see grammars, textbooks and school programs dividing the teaching of the Portuguese language into watertight segments Phonetics, Morphology and Syntax and having as appendix, respectively, the chapters of figures of syntax, historical grammar, spelling, punctuation, meaning of words and language vices.

\section{Considerations}

(...) In view of this scenario, Portuguese colonization resulted, in relation to language, constitutional, legal, political and social actions around PL as the National, State and Maternal Language of the Country. Also understanding that Brazilian schools accept exclusively the standard language and that the literate representatives of Brazilian society have lived, since the 19th century, a situation of "linguistic schizophrenia", according to Faraco (2009: 107), when the culture of "error" entered the public debate in positions on social relations and teaching Portuguese).

Cultural issues, in relation to the colonizer, also brought Lusitanian Portuguese closer to Romanticism in the post-independence period of colonial Brazil in relation to Brazilian Portuguese, understanding, for some, that in Portugal the "true" owners of the language, the founders, resided. of a pure language, thus revealing "(...) a clear understanding of the standardizing process, which takes place exactly by selecting and privileging and, at the same time, excluding forms (Faraco, 2008: 115)".

\section{Acknowledgement}

This work was carried out with support from CAPES (001 - 88882.181006/2018-01) and CNPq (132442/2019-1), through the Master's Scholarship, within the scope of Post-Graduate Program in Letters/Linguistics Studies of the Federal University of Paraná. And this work it is an excerpt from the Dissertation entitled: "Uma Análise Glotopolítica aa Concepção de Língua(gem) no Componente de Língua Portuguesa da Base Nacional Comum Curricular”, 
supervised by Professor Dr. Francisco Calvo del Olmo and co-supervised by Professor Dr. Xoán Carlos Lagares.

\section{References}

Bagno, M., \& Rangel, E. (2005). Tarefas da Educação Linguística no Brasil. Rev. Brasileira de Linguística Aplicada, 5 (1), 63-81. https://doi.org/10.1590/S1984-63982005000100004.

Bagno, M. (2011). O que é uma Língua? imaginário, ciência \& hipóstase. In X. Lagares, \& M. Bagno (Orgs.). Políticas da Norma e Conflitos Linguísticos (pp. 355-387). São Paulo: Parábola.

Bagno, M. (2019). Objeto Língua. São Paulo: Parábola.

Bright, W. (1992). International Encyclopedia of Linguistics. Oxford: Oxford University Press.

Cooper, R. L. (1989). Language Planning and Social Change. Cambridge University Press. https://doi.org/10.1017/CBO9780511620812

Faraco, C. A. (2004). Norma-Padrão Brasileira: desembaraçando alguns nós. In M. Bagno (Org.). Lingüística da Norma. São Paulo: Loyola.

Faraco, C. A. (2008). Norma Culta Brasileira: desatando alguns nós. São Paulo: Parábola.

Faraco, C. A. (2016). História Sociopolítica da Língua Portuguesa. São Paulo: Parábola Editorial.

Guespin, L., \& Marcellesi, J-B. (1986). Pour la Glottopolitique. Langages, 83, 5-34. https://doi.org/10.3406/lgge.1986.2493.

Johnson, D. (2013). Language Policy. Londres: Palgrave Macmillan UK. https://doi.org/10.1057/9781137316202.

Kaplan, R. B., \& Baldauf, R. B. (1997). Language Planning: From Practice to Theory. Clevedon: Multilingual Matters.

Lagares, X. C. (2018). Qual Política Linguística? desafios glotopolíticos contemporâneos. São Paulo: Parábola.

Malfacini. A. C. S. (2015). Breve Histórico do Ensino de Língua Portuguesa no Brasil: da Reforma Pombalina ao uso de Materiais Didáticos apostilados. IDIOMA, Rio de Janeiro, 28, 45-59, 1o. Sem.

Mccarty, T. L. (2011). Ethnography and Language Policy. London: Routledge.

Schiffman, H. F. (1996). Linguistic Culture and Language Policy. London: Routledge.

Spolsky, B. (2004). Language Policy. Cambridge University Pres.

Soares, M. (1996). Português na Escola: história de uma disciplina curricular. Materiais Escolares: história e sentidos. Revista de Educação. Brasília, 25.

Souza \& Del Olmo (2019). A Reflection on the Concepts and the Perceptions of Language Policy. Education and Linguistic Research, 5 (1). https://doi.org/10.5296/elr.v5i1.14506.

Spolsky, B. (2007). Towards a Theory of a Language Policy. Working Papers in Educational Linguistics (WPEL) 22/1: 1-14, Philadelphia. https://doi.org/10.1007/s10993-006-9045-0. 


\section{Macrothink}

Education and Linguistics Research

ISSN 2377-1356 2021, Vol. 7, No. 1

Tollefson, J. W. (1991). Planning Language, Planning Inequality: Language Policy in the Community. London: Longman.

Tollefson, J. W. (2013). Language Policies in Education: Critical Issues (2nd ed.). London and New York: Routledge. https://doi.org/10.4324/9780203813119.

\section{Copyright Disclaimer}

Copyright reserved by the author(s).

This article is an open-access article distributed under the terms and conditions of the Creative Commons Attribution license (http://creativecommons.org/licenses/by/4.0/). 